\title{
PENGARUH EKSTRAK RIMPANG KUNYIT (Curcuma domestica Val.), LENGKUAS (Languas galanga L.) Stunz, dan KENCUR (Kaempferia galanga L.) TERHADAP Pythium sp. SECARA IN-VITRO
}

\author{
(The Effect of Curcuma domestica Val., Languas galanga L. Stunz, and \\ Kaempferia galanga L. Rhizome Extract on Pythium sp.) \\ Ujang W. Darmawan dan/and Illa Anggraeni \\ Pusat Penelitian dan Pengembangan Peningkatan Produktivitas Hutan \\ Kampus Balitbang Kehutanan, Jl. Gunung Batu No. 5, Po. Box 311 Bogor 16118. \\ Telp. (0251)8631238, Fax. (0251) 7520005
}

Naskah masuk : 20 Januari 2012; Naskah diterima : 30 Agustus 2012

\begin{abstract}
Pythium sp. as a causal agent of damping off disease has damaged plant in the nursery. In the meantime, $\underline{\text { Curcuma }}$ domestica, Languas galanga and Kaempferia galanga have been known to have potential to produce botanical fungicide from extract of their rhizomes. This research aims to understand how these plants (rhizome extract) control the growth of fungi. Rhizomes were extracted in boiled water and the extract was mixed with Potato Dextrose Agar (PDA) media. The fungi were then grown on media and the growth rates were measured. Result states three rhizome extracts control fungi on 20\%,30\%,40\% and 50\% concentration. The best result reached by 50\% concentration of Languas galanga L. Stunz rhizome extract and inhibited 64\%, 50\% and 54\% at first, second and third day respectively.
\end{abstract}

Keywords: Curcuma domestica, Languas galanga, Kaempferia galanga, Pythium sp.

\begin{abstract}
ABSTRAK
Pythium sp. sebagai salah satu penyebab penyakit dumping off telah banyak menimbulkan kerusakan. Upaya pemanfaatan bahan kunyit (Curcuma domestica), lengkuas (Languas galanga) dan kencur (Kaempferia galanga) dilakukan sebagai alternatif pengendalian penyakit tersebut yang bersifat ramah lingkungan. Penelitian ini bertujuan untuk mengetahui pengaruh ekstrak dari rimpang ketiga jenis tanaman tersebut terhadap Pythium sp. Metode yang digunakan adalah peracunan media tumbuh PDA dengan menggunakan ekstrak dari rebusan rimpang dan menganalisa respon pertumbuhannya. Hasil penelitian ini menunjukkan bahwa ketiga ekstrak tersebut mampu mengendalikan pertumbuhan Pythium sp. pada konsentrasi 20\%,30\%,40\% dan 50\%. Hasil terbaik ditunjukkan oleh perlakuan lengkuas 50\% yang mampu mengendalikan pertumbuhan hingga $64 \%$ pada hari pertama dan menurun menjadi $60 \%$ pada hari kedua dan $54 \%$ pada hari ketiga.
\end{abstract}

Kata kunci : Curcuma domestica, Languas galanga, Kaempferia galanga, Pythium sp.

\section{PENDAHULUAN}

Faktor penting yang mendukung keberhasilan pembuatan tanaman kehutanan adalah peran persemaian yang mampu menyediakan bibit berkualitas sesuai dengan kebutuhan di lapangan. Namun terkadang peran persemaian mengalami hambatan berupa serangan penyakit, akibatnya persemaian gagal menghasilkan bibit yang sesuai dengan yang diharapkan. Salah satu penyakit yang sering menyerang bibit di persemaian adalah penyakit lodoh (damping-off) yaitu busuknya semai atau tajuk muda yang masih sukulen secara cepat. Penyakit ini disebabkan oleh sejumlah fungi penghuni tanah yang merupakan parasit fakultatif. Salah satu penyebab penyakit lodoh adalah fungi Pythium sp. Serangan Pythium sp. menyebabkan kerugian yang cukup besar pada beberapa persemaian tanaman hutan seperti Pinus sp., Acacia spp., Paraserianthes falcataria, Eucalyptus sp., dan Agathis sp. Namun karena perkembangan penyakit berjalan sangat cepat maka bibit di persemaian dalam waktu yang singkat dapat menimbulkan kematian. 
Berbagai macam usaha pengendalian terhadap penyakit yang disebabkan oleh Pythium sp. sudah banyak dilakukan, antara lain dengan perlakuan benih, kultur teknik pengendalian secara biologi dan aplikasi fungisida. Pengendalian dengan pestisida kimia lebih banyak dilakukan diantara berbagai alternatif pengendalian yang dilakukan selama ini. Banyaknya pengaruh buruk zat kimia di dalam bahan pengendalian penyakit yang menyebabkan orang berusaha menggunakan cara pengendalian yang ramah lingkungan. Kondisi tersebut yang mendorong berkembangnya penelitian tentang pemanfaatan bahan hayati dan pestisida nabati untuk pengendalian penyakit tanaman. Pertimbangan tersebut cukup beralasan karena penggunaan bahan-bahan yang berasal dari alam lebih mudah terurai dan tidak terakumulasi menjadi racun bagi produk tanaman.

Tujuan penelitian ini adalah untuk mengetahui pengaruh ekstrak rimpang kunyit (Curcuma domestica), lengkuas (Languas galanga) dan kencur (Kaempferia galanga) terhadap Pythium sp. penyebab penyakit lodoh pada persemaian tanaman hutan secara in-vitro.

\section{BAHAN DAN METODE}

\section{A. Waktu dan Lokasi Penelitian}

Penelitian dilaksanakan di Laboratorium Penyakit Hutan, Kelompok Peneliti Perlindungan Hutan, Pusat Penelitian dan Pengembangan Peningkatan Produktivitas Hutan Bogor, pada bulan Agustus sampai dengan Oktober 2011.

\section{B. Bahan dan Alat}

Bahan yang digunakan adalah rimpang kunyit ( $C$. domestica), lengkuas ( $L$. galanga), dan kencur (K. galanga), biakan murni Pythium $\mathrm{sp}$. (isolat dari bibit pinus yang terserang lodoh), media agar kentang $(\mathrm{PDA}=$ Potato Dextrose Agar) dan bahan kima lainnya (alkohol 70\%, spiritus, akuades) dan kapas.

Alat yang digunakan meliputi kantong plastik tahan panas, plastic wrap, cawan petri, tabung reaksi, timbangan, pelubang gabus, jarum ose, pinset, pembakar Bunsen, panci pemanas, pisau, oven, autoclave, laminar air flow (ruang isolasi) dan lain-lain.

\section{Metode \\ 1. Tahapan Kegiatan}

Penelitian dilakukan dengan mempersiapkan alat dan bahan yang diperlukan terlebih dahulu yang meliputi sterilisasi alat dan mempersiapkan bahan (isolat murni Pythium sp., PDA dan ekstrak bahan) sekaligus menjaga kondisi lingkungan agar tetap steril sesuai suhu kamar. Isolat murni diperoleh dari biakan berumur 5 hari dari koleksi di laboratorium, sedangkan pembuatan bahan larutan (ekstrak) dilakukan dengan cara mencuci bersih rimpang dengan air, dicincang kemudian direbus dengan air mendidih. Bahan dengan berat 250 gram per jenis direbus dalam satu liter air hingga mendidih dan sampai tersisa air setengahnya $(500 \mathrm{ml})$.

\section{Metode Penelitian}

Media tumbuh perlakuan disiapkan dengan cara mencampurkan larutan ekstrak dengan PDA cair sesuai dengan taraf konsentrasi dalam cawan petri ukuran $20 \mathrm{ml}$. Konsentrasi yang digunakan dalam penelitian ini adalah $10 \%$, $20 \%, 30 \%, 40 \%$, dan $50 \%$ dengan rumus :

$$
\text { Konsentrasi }=\frac{\text { volume ekstrak }}{\text { vol. Ekstrak }+ \text { vol. PDA }}
$$

Media tumbuh perlakuan yang tersedia kemudian disterilkan dalam autoclave dengan suhu $121^{\circ} \mathrm{C}$ dan tekanan 1 atmosfer selama 25 menit. Media tumbuh perlakuan yang telah disterilkan kemudian diangkat dan didiamkan hingga membeku di dalam laminar air flow yang telah disterilkan dengan alkohol $70 \%$. Setelah membeku kemudian ditanam inokulum dari Pythium sp.

Inokulum yang ditanam berupa lempengan berdiameter $0,5 \mathrm{~cm}$ dengan menggunakan cork borer yang disterilkan dengan cara dibakar di atas pembakar Bunsen. Media tumbuh cawan petri yang berisi inokulum kemudian dipasangkan plastic wrap agar tidak terkontaminasi.

\section{Rancangan Penelitian}

Percobaan ini dilakukan dengan menggunakan metode Rancangan Acak Lengkap (RAL) dengan tiga perlakuan berupa ekstrak bahan yaitu lengkuas ( $\mathrm{Lg}$ ), kunyit (Ky) dan kencur $(\mathrm{Kc})$. Masing-masing bahan tersebut diuji 
pada lima taraf konsentrasi yaitu 10\%, 20\%, $30 \%, 40 \%$, dan $50 \%$ dengan sepuluh ulangan dengan kontrol berupa PDA tanpa perlakuan sebagai pem-banding. Peubah yang diamati adalah jari-jari koloni yang diukur dari pusat inokulum diletakkan sampai lingkaran luar koloni. Pengamatan dilakukan setiap hari terhadap pertumbuhan diameter koloni pada waktu yang sama hingga koloni memenuhi cawan Petri.

Nilai penghambatan setiap perlakuan diketahui dengan menghitung persentase penghambatan dengan menggunakan formula sebagai berikut:

$$
\% \text { penghambatan }=\frac{\mathrm{A}-\mathrm{B}}{\mathrm{A}} \times 100 \%
$$

Keterangan:

A $=$ jari-jari koloni tanpa perlakuan (kontrol)

$\mathrm{B}=$ jari-jari koloni perlakuan

\section{Analisis Data}

Data dari hasil pengamatan yang berupa pertumbuhan jari-jari koloni diolah dengan perangkat lunak SPSS untuk mengetahui pengaruh setiap perlakuan terhadap pertumbuhan koloni. Pengaruh yang ditunjukkan melalui pertumbuhan jari-jari koloni diuji beda rata-rata antara perlakuan dan dibandingkan dengan kontrol menggunakan uji Tukey pada taraf uji $5 \%$.

\section{HASIL DAN PEMBAHASAN}

\section{A. Hasil}

Analisa uji nilai tengah data hasil pengamatan menunjukkan bahwa secara umum perlakuan yang diberikan terhadap Pythium sp. memberikan pengaruh yang nyata (Tabel 1 ). Selama tiga hari pengamatan, pertumbuhan jari-jari koloni bervariasi di antara perlakuan. Perlakuan dengan konsentrasi 10\% (Lg, Kc dan $\mathrm{Ky}$ ) menunjukkan hasil yang tidak berbeda nyata dengan kontrol pada pengamatan hari pertama, kedua maupun ketiga baik pertumbuhan koloni (Gambar 1) maupun persentase penghambatannya (Gambar 2).

Tabel (Table) 1. Uji nilai tengah pertumbuhan dan persentase penghambatan terhadap Pythium sp. pada beberapa perlakuan (Significant different test on Pythium sp. growth ( $\mathrm{mm}$ ) and inhibitory percentage (\%) of several treatments)

\begin{tabular}{|c|c|c|c|c|c|c|c|c|c|c|c|c|}
\hline \multirow{3}{*}{$\begin{array}{l}\text { Perlakuan } \\
\text { (Treatment) }\end{array}$} & \multicolumn{4}{|c|}{ Hari 1(Day 1) } & \multicolumn{4}{|c|}{ Hari 2(Day 2) } & \multicolumn{4}{|c|}{ Hari 3(Day 3) } \\
\hline & \multicolumn{2}{|c|}{$\begin{array}{c}\text { Jari-Jari } \\
\text { (Radius) } \\
(\mathrm{mm})\end{array}$} & \multicolumn{2}{|c|}{$\begin{array}{c}\text { Persen } \\
\text { Penghambatan } \\
\text { (Inhibitory } \\
\text { Percentage) } \\
(\%) \\
\end{array}$} & \multicolumn{2}{|c|}{$\begin{array}{c}\text { Jari-Jari } \\
\text { (Radius) } \\
(\mathrm{mm})\end{array}$} & \multicolumn{2}{|c|}{$\begin{array}{c}\text { Persen } \\
\text { Penghambatan } \\
\text { (Inhibitory } \\
\text { Percentage) } \\
(\%) \\
\end{array}$} & \multicolumn{2}{|c|}{$\begin{array}{c}\text { Jari-Jari } \\
(\text { Radius }) \\
(\mathrm{mm})\end{array}$} & \multicolumn{2}{|c|}{$\begin{array}{c}\text { Persen } \\
\text { Penghambatan } \\
\text { (Inhibitory } \\
\text { Percentage) } \\
(\%) \\
\end{array}$} \\
\hline & 12,4 & $\mathrm{a}$ & 0,0 & $\mathrm{a}$ & 26,3 & A & 0 & $\mathrm{a}$ & 38,4 & $\mathrm{a}$ & 0,0 & $\mathrm{a}$ \\
\hline Lg 10\% & 10,7 & bc & 12,7 & bcd & 24,6 & B & 6,4 & $a b$ & 35,6 & $a b c$ & 6,8 & $a b c$ \\
\hline Kc $10 \%$ & 11,9 & $\mathrm{a}$ & 3,4 & $\mathrm{ab}$ & 24,4 & B & 7,1 & $\mathrm{~b}$ & 38,3 & $a b$ & 0,0 & $\mathrm{a}$ \\
\hline Ку 10\% & 10,5 & bcd & 15,1 & $\mathrm{~cd}$ & 23,7 & $\mathrm{Bc}$ & 9,9 & b & 36,1 & $a b c$ & 5,5 & $a b$ \\
\hline $\operatorname{Lg} 20 \%$ & 10,0 & bcde & 18,9 & $\mathrm{~cd}$ & 20,0 & Ef & 23,9 & def & 28,9 & gh & 24,6 & efg \\
\hline Kc $20 \%$ & 10,9 & B & 11,6 & $\mathrm{bc}$ & 22,9 & $\mathrm{C}$ & 12,7 & $\mathrm{bc}$ & 35,5 & $\mathrm{bc}$ & 7,1 & $a b c$ \\
\hline Ку $20 \%$ & 9,8 & de & 20,8 & cde & 21,5 & $\mathrm{D}$ & 18,3 & $\mathrm{~cd}$ & 34,0 & cde & 10,9 & abcd \\
\hline Lg $30 \%$ & 9,4 & ef & 23,5 & def & 17,0 & $\mathrm{H}$ & 35,1 & gh & 27,3 & hi & 28,6 & fgh \\
\hline Kc 30\% & 9,7 & de & 21,1 & cde & 20,5 & De & 21,9 & de & 35,0 & $\mathrm{~cd}$ & 8,7 & $a b c$ \\
\hline Ку $30 \%$ & 9,9 & cde & 19,7 & cde & 20,1 & Ef & 23,5 & def & 31,5 & efg & 17,8 & cdef \\
\hline $\operatorname{Lg} 40 \%$ & 7,7 & gh & 37,4 & gh & 14,3 & I & 45,6 & $\mathrm{i}$ & 22,9 & $\mathrm{j}$ & 39,8 & $\mathrm{~h}$ \\
\hline $\mathrm{Kc} 40 \%$ & 8,2 & G & 33,4 & fgh & 18,7 & G & 28,9 & $\mathrm{fg}$ & 32,2 & def & 15,2 & bcde \\
\hline Ку 40\% & 10,1 & bcde & 18,0 & $\mathrm{~cd}$ & 19,1 & $\mathrm{Fg}$ & 27,3 & ef & 29,6 & fgh & 22,7 & efg \\
\hline $\operatorname{Lg} 50 \%$ & 4,4 & I & 64,0 & efg & 10,5 & $\mathrm{~J}$ & 60,0 & $\mathrm{j}$ & 17,6 & $\mathrm{k}$ & 53,8 & $\mathrm{i}$ \\
\hline Kc $50 \%$ & 7,2 & $\mathrm{H}$ & 41,8 & $\mathrm{~h}$ & 16,8 & $\mathrm{H}$ & 36,0 & $\mathrm{~h}$ & 29,6 & fgh & 22,2 & defg \\
\hline Ку $50 \%$ & 8,6 & $\mathrm{fg}$ & 30,1 & i & 16,3 & $\mathrm{H}$ & 37,9 & $\mathrm{~h}$ & 25,5 & $\mathrm{ij}$ & 33,2 & gh \\
\hline
\end{tabular}

Keterangan (Remarks): Huruf yang sama pada kolom yang sama menunjukkan bahwa tidak ada perbedaan yang nyata (Figures followed by the same letters are not significantly different at 5\% level according to Tukey test) 


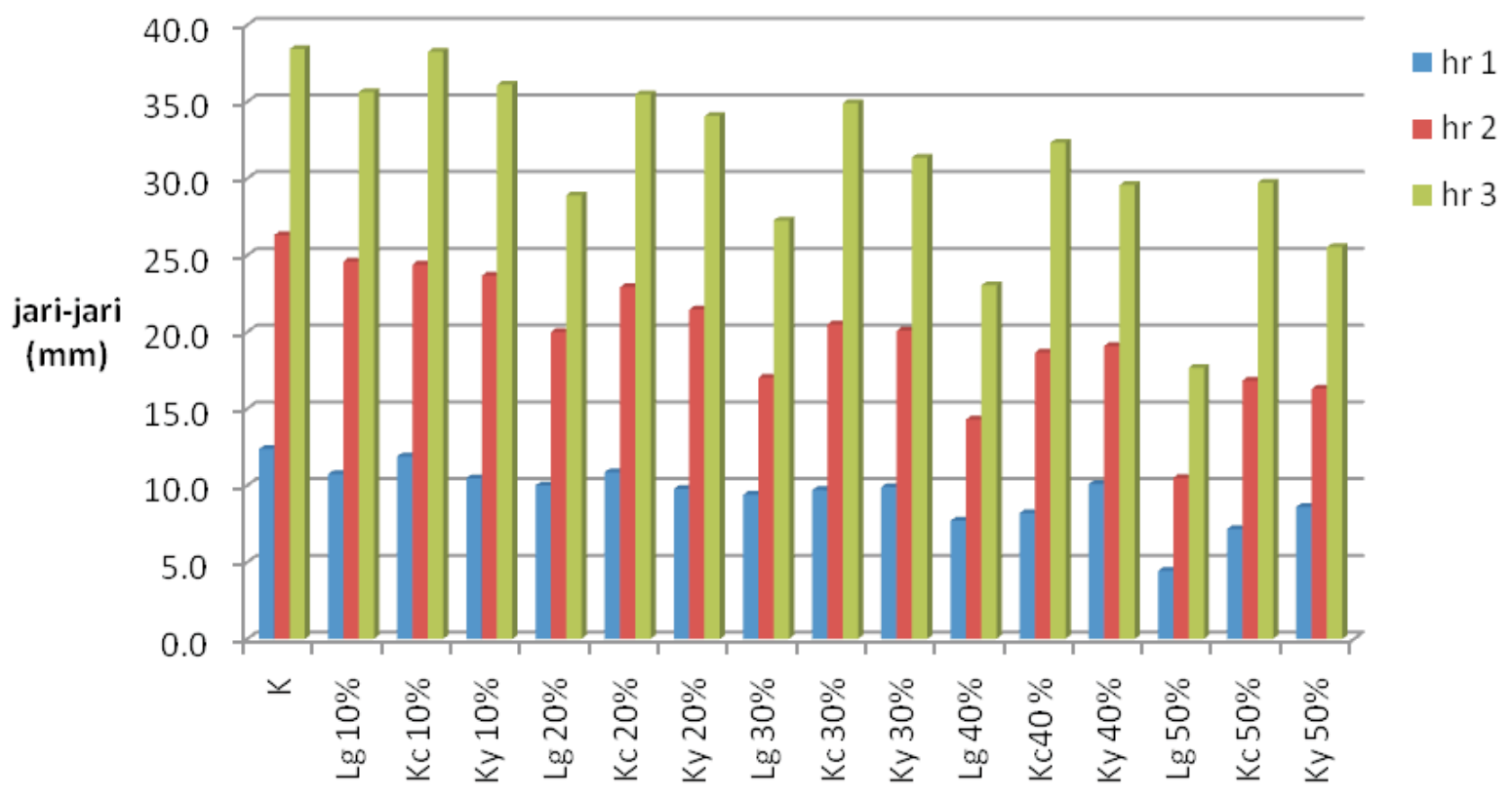

perlakuan

Gambar(Figure)1. Pertumbuhan Pythium sp. pada media tumbuh (Growing of Pythium sp. on growth media)

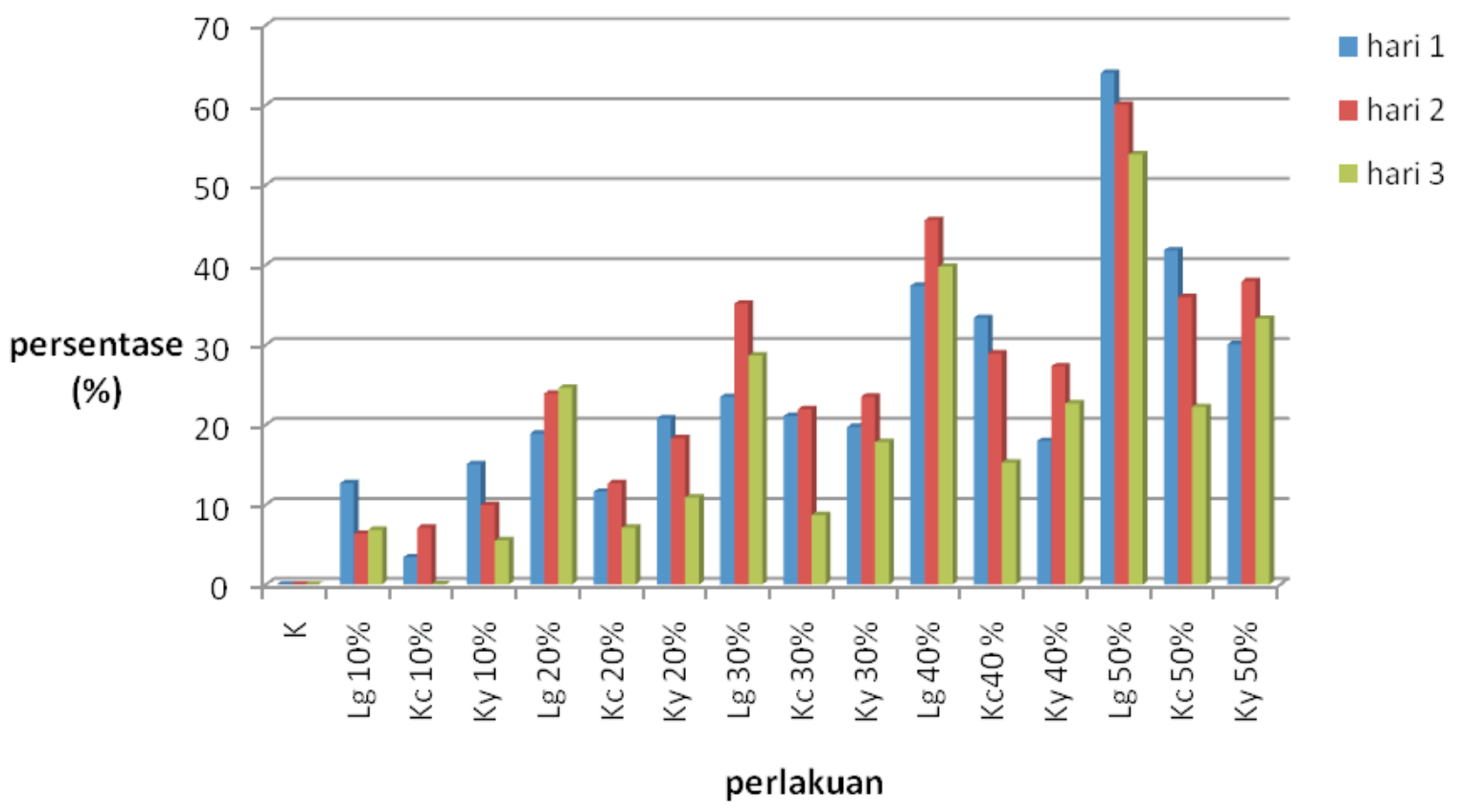

Gambar(Figure) 2. Persentase penghambatan terhadap Pythium sp. pada media tumbuh perlakuan. (Percentage of inhibitory of Pythium sp. on growth media) 
Tiga jenis ekstrak memiliki kemampuan untuk mengendalikan pertumbuhan Pythium sp. yang berbeda satu sama lain. Tabel 1 menunjukkan bahwa dengan konsentrasi yang sama, ekstrak lengkuas memiliki kemampuan mengendalikan pertumbuhan Pythium sp. lebih baik daripada jenis ekstrak yang lainnya. Perbedaan variasi ini dapat disebabkan oleh perbedaan senyawa aktif yang terkandung di dalam setiap jenis ekstrak. Pada Gambar 2 menunjukkan persentase penghambatan berbanding lurus dengan konsentrasi perlakuan. Semakin tinggi konsentrasi, maka persentase penghambatan juga semakin tinggi. Selain dipengaruhi oleh jenis dan konsentrasi ekstrak yang digunakan, kemampuan pengendalian terhadap Pythium sp. mengalami penurunan seiring waktu.

\section{B. Pembahasan}

Berdasarkan hasil penelitian ternyata senyawa aktif kencur pada konsentrasi $10 \%$ tidak mampu mengendalikan pertumbuhan Pythium sp. Berbeda dengan senyawa aktif dengan konsentrasi lebih dari $10 \%$ menunjukkan respon terhadap penekanan pertumbuhan Pythium sp. Dengan demikian kecenderungan semakin tinggi konsentrasi ekstrak memberikan pengaruh yang nyata terhadap kemampuan mengendalikan pertumbuhan koloni yang semakin baik.

Senyawa aktif pada percobaan ini diekstrak menggunakan pelarut air, sehingga hanya senyawa aktif yang bersifat larut air yang dapat terisolasi, sedangkan zat lain yang memiliki sifat kepolaran yang berbeda akan tertahan. Selain jenis dan volume zat aktif yang dikandung dalam bahan, ketiga jenis bahan ekstrak yang berbeda mungkin memiliki kandungan senyawa aktif yang berbeda terkait sifat kepolarannya. Hal ini tentu akan menyebabkan senyawa aktif yang dihasilkan dan berperan dalam pengendalian pertumbuhan fungi juga berbeda.

Ekstrak rimpang kencur mengandung komponen senyawa aktif sebagai biofungisidal bagi pertumbuhan jamur Trichophyton mentagrophytes dan Cryptococcus neoformans. Senyawa aktif yang dihasilkan melalui ekstraksi etanol tersebut yang berperan dalam pengendalian fungi antara lain adalah minyak atsiri, flavonoid, saponin dan methyl-p-methoxycin- namate, methylcinnamate, carvone, eucalyptol dan pentadecane (Gholib, 2009). Sedangkan penelitian terdahulu hasil penapisan fitokimia terhadap ekstrak etanol lengkuas mengandung alkaloid, saponin, steroid/triterpenoid, kuinon dan minyak atsiri (Gholib dan Darmono, 2008). Berdasarkan hasil ekstraksi etanol terhadap kunyit yang dilakukan oleh Chhetri et al., (2008) kunyit mengandung glikosida, terpenoid dan flavonoid.

Menurut Cowan (1999), bahan yang dapat diekstrak menggunakan pelarut air diantaranya anthocianin, starches, tannin, saponin, terpenoid, polipeptida dan lektin. Terpenoid dan saponin selain dapat larut dengan menggunakan pelarut etanol, methanol, chloroform, dichloromethanol dan ether juga dapat larut dalam air. Terpen atau terpenoid adalah senyawa aktif terhadap bakteri, fungi, virus dan protozoa.

Terpen atau terpenoid dilaporkan bersifat antifungi (Taylor et al., 1996). Senyawa ini banyak terkandung dalam tanaman aromatik yang berupa minyak atsiri (essential oil). Model mekanisme interaksi senyawa ini dengan mikroba diduga melibatkan perusakan membran oleh senyawa lipofilik (Arif et al., 2009). Sedangkan lektin dan polipeptida bereaksi dengan membentuk lubang pada membran (Zang dan Lewis, 1997) atau menghambat penyatuan protein mikroba pada reseptor polisakarida inangnya (Mirelman, 1986). Demikian juga dengan se-nyawa saponin bersifat anti fungi dan sering terdapat pada jarigan tanaman yang sehat dalam jumlah yang cukup besar, molekul ini merupakan faktor penting dalam sistem pertahanan diri tanaman dari serangan fungi (Osbourn, 1996a).

Penurunan ini mungkin disebabkan oleh proses adaptasi yang dilakukan oleh fungi. Sejumlah fungi berhasil dalam menghalau senyawa anti mikroba yang dihasilkan tanaman dengan cara menghasilkan sejenis enzim yang mampu menghilangkan sifat racun pada saponin (detoksifikasi saponin). Mekanisme semacam ini yang melibatkan detoksifikasi saponin bisa berlaku luas untuk fungi pathogen (Osbourn, 1996b). Resistensi patogen Pythium sp. dan Phytophtora sp. terhadap saponin juga dihubungkan dengan sedikitnya jumlah sterol yang terdapat pada membran sel fungi (Arneson dan Durbin, 1968 dalam Osbourn, 1996a). 


\section{KESIMPULAN}

\section{A. Kesimpulan}

1. Ekstraksi sederhana dari bahan rimpang lengkuas, kencur dan kunyit memiliki kemampuan mengendalikan pertumbuhan Pythium sp.

2. Ekstrak lengkuas menunjukkan kemampuan yang lebih baik dibandingkan dengan jenis ekstrak lainnya. Hal ini ditunjukkan oleh tingkat pengendalian pertumbuhan Pythium sampai $64 \%$.

3. Semakin tinggi konsentrasi ekstrak, kemampuan mengendalikan pertumbuhan Pythium sp. semakin baik.

\section{B. Saran}

Potensi ketiga jenis ekstrak dapat dikembangkan sebagai fungisida untuk menekan pertumbuhan Pythium sp. yang merupakan salahsatu penyebab penyakit lodoh di persemaian.

\section{DAFTAR PUSTAKA}

Arif, T., J.D. Bhosale., N.Kumar., T.K. Mandal., R.S. Bendre., G.S. Lavekara. and R. Dabur. 2009. Natural products - Antifungal Agents Derived From Plants. Journal of Asian Natural Products Research. Vol. 11, No. 7, July 2009. 621-638.

Chhetri, H.P., N.S. Yogol., J. Sherchan., K.C., Anupa., S. Mansoor. and P. Thapa. 2008. Phytochemical and Antimicrobial Evaluations Of Some Medicinal Plants Of Nepal. Kathmandu University Journal Of Science, Engineering And Technology. Vol. I, No. V, September 2008.49-54.
Cowan, M.M. 1999. Plant Products as Antimicrobial Agents, Clinical Microbiology Reviews, Oct. 1999. P. 564-582 Vol. 12, No. 4. Department Of Micro-biology, Miami University, Oxford, Ohio 45056.

Gholib, D. 2009. Daya Hambat Ekstrak Kencur (Kaempferia Galanga L.) terhadap Trichophyton Mentagrophytes dan Cryptococcus Neoformans Jamur Penyebab Penyakit Kurap Pada Kulit Dan Penyakit Paru. Bul. Littro. Vol. 20 No. 1, 2009, 59 - 67. Balai Besar Penelitian Veteriner.

Gholib, D. dan Darmono. 2008. Pengaruh Ekstrak Lengkuas Putih (Alpingia galanga L. Wild) terhadap Infeksi Trichophyton mentagrophytes pada Kelinci. Jurnal Ilmu Kefarmasian Indonesia, Vol 6 no 2, 57-62.

Osbourn, A.E. 1996a. Preformed Antimicrobial Compounds and Plant Defense Against Fungal Attack. Plant Cell 8:1821-1831

Osbourn, A.E. 1996b. Saponins and Plant Defence ; A Soap Story. Trends Plant Science. January (1996), Vol. 1, No. 1, 4-8.

Sharon, N. and I. Ofek. 1986. Mannose Specific Bacterial Surface Lectins, dalam D. Mirelman (ed.), Microbial Lectins and Agglutinins. John Wiley \& Sons, Inc., New York, N.Y.

Taylor, R.S.L., F. Edel., N.P. Manandhar and G.H.N. Towers. 1996. Antimicrobial Activities of Southern Nepalese Medicinal Plants. Journal of Ethnopharmacology. Vol. 50, Issue 2, February 1996, 97-102.

Zhang, Y. and K. Lewis. 1997. Fabatins: New Antimicrobial Plant Peptides. FEMS Microbiology Letters. Vol.149, Issue 1, 59-64. 